\title{
ATIVIDADES DO ${ }^{226}$ Ra EM ÁGUAS SUBTERRÂNEAS EXTRAÍDAS DE DOIS POÇOS LOCALIZADOS NO PLÚTON MERIDIONAL, GRANITÓIDES DE MORUNGABA, SP
}

\author{
Fábio de Oliveira Lucas
}

Orientador: Dr. Fernando Brenha Ribeiro (IAG-USP)

80 p - Dissertação (Mestrado) - Defesa 18.05.2004

RESUMO. Atividades específicas do ${ }^{226}$ Ra dissolvido foram medidas e atividades de ${ }^{226}$ Ra associado ao material em suspensão foram estimadas em águas subterrâneas extraídas de dois poços perfurados nos granitos róseos do Plúton Meridional, Granitóides de Morungaba, no Leste do Estado de São Paulo. As atividades foram medidas em uma seqüência de amostras coletadas em período de nove meses, entre março e dezembro de 2003. As atividades específicas médias do ${ }^{226}$ Ra dissolvido nas águas dos dois poços foram respectivamente $(43,8 \pm 7,2) \mathrm{mBq} / \mathrm{L}$ e $(51,2 \pm 8,8) \mathrm{mBq} / \mathrm{L}$. Não se observou nenhuma tendência significativa de variação das atividades específicas como função do tempo. Os valores atividades específicas permitiram calcular a contribuição do ${ }^{226} \mathrm{Ra}$, associada à ingestão dessas águas para a dose equivalente comprometida na superfície dos ossos, $(0,0114 \pm 0,0019) \mathrm{mSv} / \mathrm{a}$ e $(0,0134 \pm 0,0023) \mathrm{mSv} / \mathrm{a}$, respectivamente, e para dose equivalente comprometida efetiva, respectivamente, $(0,219$ $\pm 0,044) \mathrm{mSv} / \mathrm{a}$. As atividades do ${ }^{226} \mathrm{Ra}$ associadas ao material em suspensão em um litro de água variam entre, aproximadamente, $1 \mathrm{mBq} / \mathrm{L} \mathrm{e}$ $10 \mathrm{mBq} / \mathrm{L}$.

ABSTRACT. Specific activities of dissolved ${ }^{226} \mathrm{Ra}$ isotope were measured and ${ }^{226} \mathrm{Ra}$ isotope activities associated to suspended solids were estimated in ground waters drawn from two wells drilled in a fractured granitic aquifer of the Meridional Pluton, Morungaba Granitoids, eastern São Paulo State. The ${ }^{226} \mathrm{Ra}$ isotope activities were measured in a nine month sampling sequence between March and December, 2003. The mean dissolved ${ }^{226}$ Ra specific activities were, respectively, $(43.8 \pm 7.2) \mathrm{mBq} / \mathrm{L}$ and $(51.2 \pm 8.8) \mathrm{mBq} / \mathrm{L}$. None significant time dependent trends were observed. The ${ }^{226} \mathrm{Ra}$ isotope contribution to the bone surface committed dose, associated with the ingestion of these waters, were calculated as, respectively, $(0.0224 \pm 0.0019) \mathrm{mSv} /$ year and $(0.0134 \pm 0.0023) \mathrm{mSv} / \mathrm{year}$. The contribution to the effective committed dose were calculate as $(0.219 \pm 0.040) \mathrm{mSv} /$ year and $(0.258 \pm 0.044) \mathrm{mSv} /$ year, respectively. The estimates of the activities of the ${ }^{226} \mathrm{Ra}$ activities of the suspended solids in a liter of these waters varied between, $1 \mathrm{mBq} / \mathrm{L}$ and $10 \mathrm{mBq} / \mathrm{L}$. 